\title{
Human IgG and IgA responses to COVID-19 mRNA vaccines
}

\author{
Adam V. Wisnewski $\oplus^{\bullet *}$, Julian Campillo Luna $\oplus^{\circ}$, Carrie A. Redlich \\ Department of Internal Medicine, Yale University School of Medicine, New Haven, Connecticut, United States \\ of America \\ ه These authors contributed equally to this work. \\ * adam.wisnewski@yale.edu
}

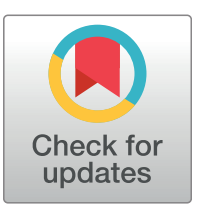

\section{Gopenaccess}

Citation: Wisnewski AV, Campillo Luna J, Redlich CA (2021) Human IgG and IgA responses to COVID-19 mRNA vaccines. PLOS ONE 16(6): e0249499. https://doi.org/10.1371/journal. pone.0249499

Editor: Aftab A. Ansari, Emory University School of Medicine, UNITED STATES

Received: March 23, 2021

Accepted: May 30, 2021

Published: June 16, 2021

Copyright: @ 2021 Wisnewski et al. This is an open access article distributed under the terms of the Creative Commons Attribution License, which permits unrestricted use, distribution, and reproduction in any medium, provided the original author and source are credited.

Data Availability Statement: All relevant data are within the manuscript and its Supporting information files.

Funding: National Institute for Occupational Safety and Health, 5T030H008607-15, to Dr. Carrie A Redlich.

Competing interests: The authors have declared that no competing interests exist.

\section{Abstract}

SARS-CoV-2 spike antigen-specific IgG and IgA elicited by infection mediate viral neutralization and are likely an important component of natural immunity, however, limited information exists on vaccine induced responses. We measured COVID-19 mRNA vaccine induced $\lg G$ and IgA in serum serially, up to 145 days post vaccination in 4 subjects. Spike antigenspecific IgG levels rose exponentially and plateaued 21 days after the initial vaccine dose. After the second vaccine dose IgG levels increased further, reaching a maximum approximately 7-10 days later, and remained elevated (average of 58\% peak levels) during the additional $>100$ day follow up period. COVID-19 mRNA vaccination elicited spike antigenspecific IgA with similar kinetics of induction and time to peak levels, but more rapid decline in serum levels following both the $1^{\text {st }}$ and $2^{\text {nd }}$ vaccine doses (<18\% peak levels within 100 days of the $2^{\text {nd }}$ shot). The data demonstrate COVID-19 mRNA vaccines effectively induce spike antigen specific $\lg G$ and $\lg A$ and highlight marked differences in their persistence in serum.

\section{Introduction}

Humoral responses are key components of adaptive immunity to viral infection [1]. Both alpha and gamma immunoglobulins (Ig) from COVID-19 patients mediate viral neutralization and may play distinct roles in immunity during different phases of infection and at specific anatomical sites [2-5]. IgA is the most abundantly produced Ig in humans $(66 \mathrm{gm} / \mathrm{kg} / \mathrm{day})$ and the most abundant isotype at mucosal sites while IgG is major isotype in blood and most tissues $[6,7]$.

IgA's anatomical distribution at mucosal surfaces exposed to infectious agents makes it uniquely positioned to intervene in transmission. Multiple studies have found IgA possesses superior anti-viral properties vs. IgG for influenza and for SARS-CoV-2 [8-11]. Sterlin et. al [11] recently suggested IgA dominates the early neutralizing response to SARS-CoV-2 based on multiple findings; serum IgA is 7-fold more potent than serum IgG in viral neutralization, temporal changes in circulating IgA+ plasmablasts with mucosal homing receptors, and the presence of neutralizing IgA in airway fluid and saliva. 
The major SARS-CoV-2 antigenic target of human IgG and IgA is the spike protein, which is encoded by the mRNA of vaccines currently in use under EUA from the FDA [12-15]. The time course of mRNA vaccine-induced IgG responses observed during vaccine trials have recently been published $[13,14]$. However, limited information exists on mRNA vaccine induced IgA responses [16]. The present study measures SARS-CoV-2 spike antigen specific serum IgA and IgG longitudinally in healthy individuals without prior COVID-19 who were among the first vaccine recipients outside of clinical trials due to their occupation as health care workers. Data from up to 80 days after the first mRNA vaccine dose are presented.

\section{Materials and methods}

Human subjects: This study was approved by the Yale University Institutional Review Board. All subjects provided written informed consent to participate. Volunteers from an ongoing serology study of health care workers were recruited to have their SARS-CoV-2 spike antigenspecific antibody levels followed over time after vaccination with SARS-CoV-2 mRNA. Subjects provided $3 \mathrm{cc}$ of blood by venipuncture using vacutainer tubes, serum was separated and stored frozen at $-80^{\circ} \mathrm{C}$ until tested by enzyme linked immunosorbent assay (ELISA). The studies were reviewed by the Yale University Human Investigation Committee and ethical approval was given by the Yale university Institutional Review Board, protocol \# 2000027749.

ELISA methods: ELISAs were performed as previously described with minor modifications $[17,18]$. In short, Triton X-100 and RNase A were added to serum samples at final concentrations of $0.5 \%$ and $0.5 \mathrm{mg} / \mathrm{ml}$ respectively and incubated at room temperature (RT) for $30 \mathrm{~min}$ utes before use to reduce risk from any potential virus in serum. 96-well MaxiSorp plates (ThermoFisher, Waltham, MA) were coated with $50 \mu \mathrm{L} /$ well of recombinant SARS Cov-2 S1 or nucleocapsid protein (Abcam, Cambridge, MA) at a concentration of $1 \mu \mathrm{g} / \mathrm{ml}$ in $\mathrm{NaCO}_{3}$ buffer $\mathrm{pH} 9.6$ and incubated overnight at $4^{\circ} \mathrm{C}$. The coating buffer was removed, and plates were incubated for $1 \mathrm{~h}$ at RT with $200 \mu \mathrm{l}$ of blocking solution (PBS with $3 \%$ milk powder). Serum was diluted 1:100 in dilution solution (PBS with 0.05\% Tween 20, 1\% milk powder) and $100 \mu \mathrm{l}$ of diluted serum was added for one hours at RT. Plates were washed three times with PBS-T (PBS with 0.1\% Tween-20) and $50 \mu \mathrm{L}$ of HRP anti-Human IgG Antibody (Parmingen/ BD Biosiences, San Jose, CA) or HRP anti-human IgA (BioLegend, San Diego, CA) were added at 1:2000-fold dilution. After $1 \mathrm{~h}$ of incubation at RT, plates were washed three times with PBS-T. Plates were developed with $100 \mu \mathrm{L}$ of TMB Substrate Reagent Set (BD Biosciences, San Jose, CA) and the reaction was stopped when an internal pooled serum positive control sample reaches an OD of 1.0 at $650 \mathrm{~nm}$, by the addition of $2 \mathrm{~N}$ sulfuric acid. Plates were then read at a wavelength of $450 \mathrm{~nm}$ with reference wavelength calibration $(650 \mathrm{~nm})$.

Statistical analysis: GraphPad Prism (v8) was used for statistical analyses. Differences in rates of SARS-CoV-2 spike antigen-specific IgG and IgA decreases (slopes fitted by exponential decay curves) and time to peak levels were assessed with Mann-Whitney U-test.

\section{Results \& discussion}

Serum levels of SARS-CoV-2 spike antigen (S1 subunit)-specific IgG and IgA were measured by ELISA over time in $\mathrm{N}=4$ health care workers that received COVID-19 mRNA vaccine between December 2020 and February 2021 (Table 1). The subjects had no prior history of COVID-19 and tested negative for SARS-CoV-2 nucleocapsid antigen and spike antigen at baseline. Additional information on average ELISA OD values is provided in supporting information S1 Table.

As shown in Fig 1, vaccine-induced serum levels of SARS-CoV-2 spike-specific IgG rose exponentially and reached a plateau approximately $18-21$ days after the $1^{\text {st }} \mathrm{mRNA}$ vaccine 
Table 1. Study subjects that received COVID-19 mRNA vaccine.

\begin{tabular}{c|c|c|c}
\hline Subject \# & Sex & Age & Vaccine \\
\hline 1 & F & 59 & Moderna \\
\hline 2 & M & 54 & Moderna \\
\hline 3 & M & 23 & Moderna \\
\hline 4 & M & 24 & Pfizer-BioNTech \\
\hline
\end{tabular}

https://doi.org/10.1371/journal.pone.0249499.t001

dose. After the $2^{\text {nd }}$ vaccine dose, SARS-CoV-2 spike-specific serum IgG increased further, peaking approximately 7 days later, and remaining elevated (58\% of peak values) during the additional $>100$ day follow-up period.

COVID-19 mRNA vaccine also elicited spike antigen-specific IgA with similar kinetics of induction and time to maximal levels after the $1^{\text {st }}$ and $2^{\text {nd }}$ vaccine dose (Fig 2). However, the levels of spike antigen-specific IgA decreased significantly $(p<0.002)$ faster than IgG levels. Spike-specific IgA decreased to an average of $50 \%$ peak levels between the $1^{\text {st }}$ and $2^{\text {nd }}$ vaccine shots, and fell to $18 \%$ of peak levels within the $>100$ day follow-up period after the $2^{\text {nd }}$ shot.

The induction and decay of antigen specific IgG and IgA in response to the novel COVID19 mRNA vaccine are consistent with the known serum $1 / 2$ lives of the different immunoglobulin isotypes; 21-28 days for gamma and 5-6 days for alpha [19-21]. The rapid decay in serum IgA levels is also consistent with that observed in natural disease among health care workers in a Spanish hospital after 3 months of follow-up [22]. Recent studies document that while SARS-CoV-2 spike-specific serum IgA levels decline quickly after infection, local concentrations at mucosal surfaces persist longer and include dimeric isoforms with potent neutralizing capacity, $15 \mathrm{X}$ greater than monomeric IgA $[10,11]$.

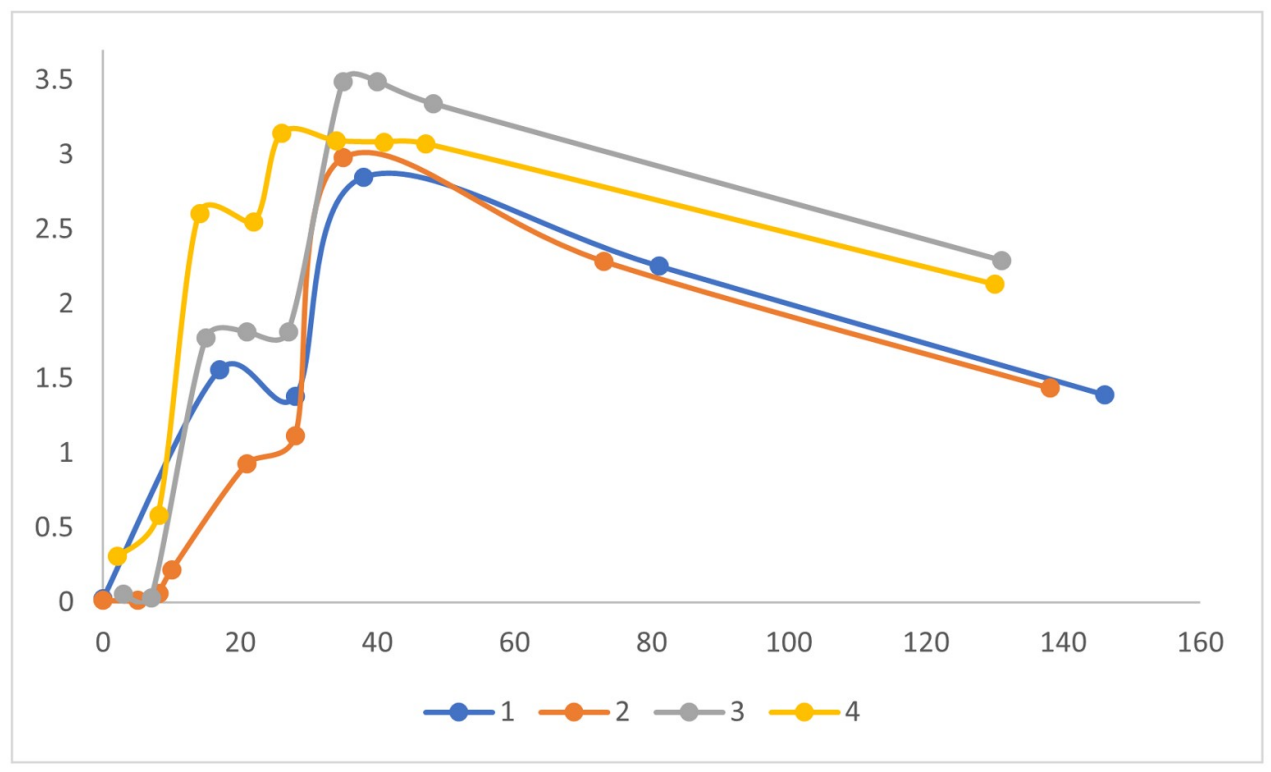

Fig 1. Time course of spike antigen-specific IgG response to COVID-19 mRNA vaccine. ELISAs were performed on serum from 4 subjects described in Table 1, at different time points after vaccination (X-axis, days). Serum IgG levels are proportional to ELISA optical density values (Y-axis). Each symbol represents average ELISA data for a single subject at a single time point. Scatter plots were fitted with a moving average trend line. Note $2^{\text {nd }}$ vaccine dose was at day 28 for subjects $1-3$, and day 21 for subject 4 .

https://doi.org/10.1371/journal.pone.0249499.g001 


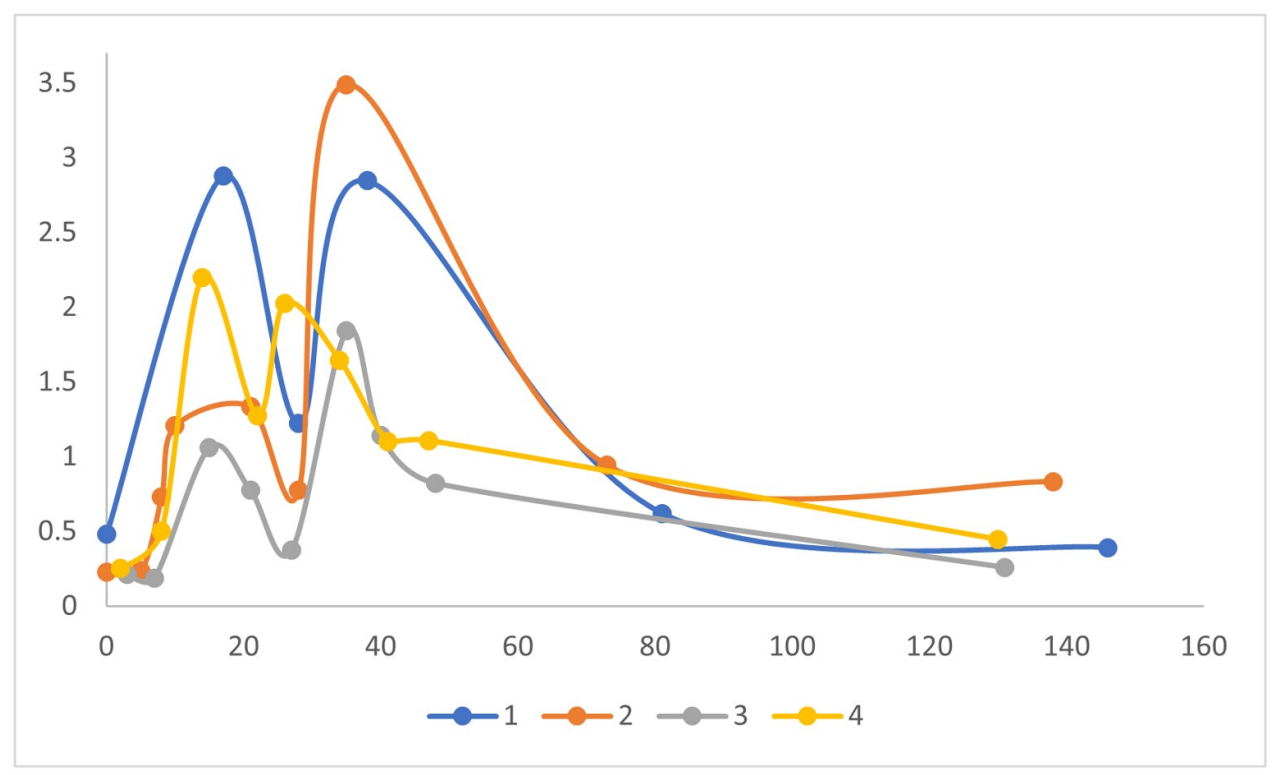

Fig 2. Time course of spike antigen-specific IgA response to COVID-19 mRNA vaccine. ELISAs were performed on serum from 4 subjects described in Table 1, at different time points after vaccination (X-axis, days). Serum IgA levels are proportional to ELISA optical density values (Y-axis). Each symbol represents average ELISA data for a single subject at a single time point. Scatter plots were fitted with a moving average trend line. Note $2^{\text {nd }}$ vaccine dose was at day 28 for subjects $1-3$, and day 21 for subject 4 .

https://doi.org/10.1371/journal.pone.0249499.g002

This study focused on serum IgA which has been shown to be clonally related to mucosal IgA, but did not measure vaccine-induced, antigen-specific mucosal IgA levels. Serum IgA may reach mucosal surfaces by transduction or via recirculating IgA secreting plasmablasts with a mucosal homing profile [23-25]. However, "local" B-cells may also undergo isotype class switching in the mucosal microenvironment and secrete IgA with distinct kinetics [26]. The present data underscore the current knowledge gap surrounding COVID-19 mRNA vaccine-induced IgA production and distribution at mucosal sites.

The major weakness of the present study is the limited number of subjects analyzed. Additional studies on a larger group of vaccinated individuals over a longer time period will be necessary to determine if the data are reflective of the general population, or if differences exist due to genetics and/or environment. The present study subjects were SARS-CoV-2 naïve, and it will be important to understand potential differences in vaccine responses of prior COVID19 subjects.

\section{Conclusions}

In summary, longitudinal serology of COVID-19 mRNA vaccine recipients highlights important issues related to immunity and monitoring of vaccine responses. The persistence of spike antigen-specific serum IgG following vaccination is hopefully a positive indicator of effective long-lived immunity, and clinical indicator of vaccine responsiveness [27]. In addition to IgG, the data demonstrate COVID-19 mRNA vaccines also elicit antigen-specific IgA, which may be important in preventing transmission as well as infection [28,29]. Spike-specific serum IgA levels decay significantly $(\mathrm{p}<0.002)$ faster than spike-specific IgG, however, the "recall" response for both $\operatorname{IgG}$ and IgA (time to peak serum levels following the $2^{\text {nd }} /$ booster dose) is significantly $(\mathrm{p}<0.03)$ shorter than the primary response. 


\section{Supporting information}

S1 Table. ELISA OD values of participants at different time points after COV ID-19 vaccine.

(PDF)

\section{Acknowledgments}

We would like to acknowledge the dedicated efforts of the Yale Occupational Medicine Fellows, Residents and Students for their participation in the present vaccine surveillance efforts.

\section{Author Contributions}

Conceptualization: Adam V. Wisnewski.

Data curation: Adam V. Wisnewski, Julian Campillo Luna, Carrie A. Redlich.

Formal analysis: Adam V. Wisnewski, Julian Campillo Luna, Carrie A. Redlich.

Funding acquisition: Adam V. Wisnewski, Carrie A. Redlich.

Investigation: Adam V. Wisnewski, Julian Campillo Luna, Carrie A. Redlich.

Methodology: Adam V. Wisnewski, Julian Campillo Luna.

Project administration: Adam V. Wisnewski, Carrie A. Redlich.

Resources: Adam V. Wisnewski, Julian Campillo Luna, Carrie A. Redlich.

Software: Adam V. Wisnewski.

Supervision: Adam V. Wisnewski, Julian Campillo Luna.

Validation: Adam V. Wisnewski, Carrie A. Redlich.

Visualization: Adam V. Wisnewski, Carrie A. Redlich.

Writing - original draft: Adam V. Wisnewski, Julian Campillo Luna, Carrie A. Redlich.

Writing - review \& editing: Adam V. Wisnewski, Julian Campillo Luna, Carrie A. Redlich.

\section{References}

1. Dörner T, Radbruch A. Antibodies and B cell memory in viral immunity. Immunity. 2007; 27(3):384-92. Epub 2007/09/26. https://doi.org/10.1016/j.immuni.2007.09.002 PMID: 17892847.

2. Wang Z, Lorenzi JCC, Muecksch F, Finkin S, Viant C, Gaebler C, et al. Enhanced SARS-CoV-2 neutralization by dimeric IgA. Sci Transl Med. 2021; 13(577). Epub 2020/12/09. https://doi.org/10.1126/ scitranslmed.abf1555 PMID: 33288661

3. Klingler J, Weiss S, Itri V, Liu X, Oguntuyo KY, Stevens C, et al. Role of IgM and IgA Antibodies in the Neutralization of SARS-CoV-2. J Infect Dis. 2020. Epub 2020/12/29. https://doi.org/10.1101/2020.08. 18.20177303 PMID: 33173891

4. Maeda K, Higashi-Kuwata N, Kinoshita N, Kutsuna S, Tsuchiya K, Hattori SI, et al. Neutralization of SARS-CoV-2 with IgG from COVID-19-convalescent plasma. Sci Rep. 2021; 11(1):5563. Epub 2021/ 03/12. https://doi.org/10.1038/s41598-021-84733-5 PMID: 33692457

5. Salazar E, Kuchipudi SV, Christensen PA, Eagar T, Yi X, Zhao P, et al. Convalescent plasma antiSARS-CoV-2 spike protein ectodomain and receptor-binding domain IgG correlate with virus neutralization. J Clin Invest. 2020; 130(12):6728-38. Epub 2020/09/11. https://doi.org/10.1172/JCl141206 PMID: 32910806

6. Underdown BJ. IgA. In: Delves PJ, editor. Encyclopedia of Immunology ( Second Edition). Oxford: Elsevier; 1998. p. 1196-9.

7. Vidarsson G, Dekkers G, Rispens T. IgG subclasses and allotypes: from structure to effector functions. Frontiers in immunology. 2014; 5:520-. https://doi.org/10.3389/fimmu.2014.00520 PMID: 25368619. 
8. Muramatsu M, Yoshida R, Yokoyama A, Miyamoto H, Kajihara M, Maruyama J, et al. Comparison of antiviral activity between IgA and IgG specific to influenza virus hemagglutinin: increased potential of IgA for heterosubtypic immunity. PLoS One. 2014; 9(1):e85582. Epub 2014/01/28. https://doi.org/10. 1371/journal.pone.0085582 PMID: 24465606

9. Liew FY, Russell SM, Appleyard G, Brand CM, Beale J. Cross-protection in mice infected with influenza $A$ virus by the respiratory route is correlated with local IgA antibody rather than serum antibody or cytotoxic T cell reactivity. Eur J Immunol. 1984; 14(4):350-6. Epub 1984/04/01. https://doi.org/10.1002/eji. 1830140414 PMID: 6609824.

10. Wang Z, Lorenzi JCC, Muecksch F, Finkin S, Viant C, Gaebler C, et al. Enhanced SARS-CoV-2 neutralization by dimeric IgA. Science Translational Medicine. 2021; 13(577):eabf1555. https://doi.org/10 1126/scitranslmed.abf1555 PMID: 33288661

11. Sterlin D, Mathian A, Miyara M, Mohr A, Anna F, Claër L, et al. IgA dominates the early neutralizing antibody response to SARS-CoV-2. Science Translational Medicine. 2021; 13(577):eabd2223. https://doi org/10.1126/scitransImed.abd2223 PMID: 33288662

12. Anderson EJ, Rouphael NG, Widge AT, Jackson LA, Roberts PC, Makhene M, et al. Safety and Immunogenicity of SARS-CoV-2 mRNA-1273 Vaccine in Older Adults. N Engl J Med. 2020; 383(25):242738. Epub 2020/09/30. https://doi.org/10.1056/NEJMoa2028436 PMID: 32991794

13. Jackson LA, Anderson EJ, Rouphael NG, Roberts PC, Makhene M, Coler RN, et al. An mRNA Vaccine against SARS-CoV-2-Preliminary Report. N Engl J Med. 2020; 383(20):1920-31. Epub 2020/07/15. https://doi.org/10.1056/NEJMoa2022483 PMID: 32663912

14. Polack FP, Thomas SJ, Kitchin N, Absalon J, Gurtman A, Lockhart S, et al. Safety and Efficacy of the BNT162b2 mRNA Covid-19 Vaccine. N Engl J Med. 2020; 383(27):2603-15. Epub 2020/12/11. https:// doi.org/10.1056/NEJMoa2034577 PMID: 33301246

15. Walsh EE, Frenck RW Jr., Falsey AR, Kitchin N, Absalon J, Gurtman A, et al. Safety and Immunogenicity of Two RNA-Based Covid-19 Vaccine Candidates. N Engl J Med. 2020; 383(25):2439-50. Epub 2020/10/15. https://doi.org/10.1056/NEJMoa2027906 PMID: 33053279

16. Jackson LA, Roberts PC, Graham BS. A SARS-CoV-2 mRNA Vaccine-Preliminary Report. Reply. N Engl J Med. 2020; 383(12):1191-2. Epub 2020/08/20. https://doi.org/10.1056/NEJMc2026616 PMID: 32813942.

17. Mahajan S, Redlich CA, Wisnewski AV, Fazen LE, Rao LV, Kuppusamy K, et al. Performance of Abbott Architect, Ortho Vitros, and Euroimmun Assays in Detecting Prior SARS-CoV-2 Infection. medRxiv. 2020:2020.07.29.20164343. https://doi.org/10.1101/2020.07.29.20164343

18. Amanat F, Stadlbauer D, Strohmeier S, Nguyen THO, Chromikova V, McMahon M, et al. A serological assay to detect SARS-CoV-2 seroconversion in humans. Nature Medicine. 2020; 26(7):1033-6. https:// doi.org/10.1038/s41591-020-0913-5 PMID: 32398876

19. Curtis J, Bourne FJ. Half-lives of immunoglobulins IgG, IgA and IgM in the serum of new-born pigs. Immunology. 1973; 24(1):147-55. Epub 1973/01/01. PMID: 4685369

20. Mankarious S, Lee M, Fischer S, Pyun KH, Ochs HD, Oxelius VA, et al. The half-lives of IgG subclasses and specific antibodies in patients with primary immunodeficiency who are receiving intravenously administered immunoglobulin. J Lab Clin Med. 1988; 112(5):634-40. Epub 1988/11/01. PMID: 3183495.

21. Salonen EM, Hovi T, Meurman O, Vesikari T, Vaheri A. Kinetics of specific IgA, IgD, IgE, IgG, and IgM antibody responses in rubella. J Med Virol. 1985; 16(1):1-9. Epub 1985/05/01. https://doi.org/10.1002/ jmv.1890160102 PMID: 3900285.

22. Moncunill G, Mayor A, Santano R, Jimenez A, Vidal M, Tortajada M, et al. SARS-CoV-2 Seroprevalence and Antibody Kinetics Among Health Care Workers in a Spanish Hospital After 3 Months of Follow-up. J Infect Dis. 2021; 223(1):62-71. Epub 2020/11/12. https://doi.org/10.1093/infdis/jiaa696 PMID: 33175145

23. Burnett D. Immunoglobulins in the lung. Thorax. 1986; 41(5):337-44. Epub 1986/05/01. https://doi.org/ 10.1136/thx.41.5.337 PMID: 3750240

24. Stockley RA, Mistry M, Bradwell AR, Burnett D. A study of plasma proteins in the sol phase of sputum from patients with chronic bronchitis. Thorax. 1979; 34(6):777-82. Epub 1979/12/01. https://doi.org/10. 1136/thx.34.6.777 PMID: 542918

25. Xiong N, Fu Y, Hu S, Xia M, Yang J. CCR 10 and its ligands in regulation of epithelial immunity and diseases. Protein Cell. 2012; 3(8):571-80. Epub 2012/06/12. https://doi.org/10.1007/s13238-012-2927-3 PMID: 22684736

26. Lin M, Du L, Brandtzaeg P, Pan-Hammarstrom Q. IgA subclass switch recombination in human mucosal and systemic immune compartments. Mucosal Immunol. 2014; 7(3):511-20. Epub 2013/09/26. https://doi.org/10.1038/mi.2013.68 PMID: 24064668. 
27. Poland GA, Ovsyannikova IG, Kennedy RB. SARS-CoV-2 immunity: review and applications to phase 3 vaccine candidates. Lancet. 2020; 396(10262):1595-606. Epub 2020/10/17. https://doi.org/10.1016/ S0140-6736(20)32137-1 PMID: 33065034

28. Russell MW, Moldoveanu Z, Ogra PL, Mestecky J. Mucosal Immunity in COVID-19: A Neglected but Critical Aspect of SARS-CoV-2 Infection. Frontiers in Immunology. 2020; 11(3221). https://doi.org/10. 3389/fimmu.2020.611337 PMID: 33329607

29. Bleier BS, Ramanathan M Jr., Lane AP. COVID-19 Vaccines May Not Prevent Nasal SARS-CoV-2 Infection and Asymptomatic Transmission. Otolaryngol Head Neck Surg. 2021; 164(2):305-7. Epub 2020/12/16. https://doi.org/10.1177/0194599820982633 PMID: 33320052. 